\title{
The calcium-dependent protease of Loxosceles gaucho venom acts preferentially upon red cell band 3 transmembrane protein
}

O.C. de O. Barretto ${ }^{1}$, M. Satake ${ }^{2}$, K. Nonoyama ${ }^{3}$ and J.L.C. Cardoso ${ }^{4}$

\section{Correspondence}

O.C. de O. Barretto

Av. Pedroso de Morais, 70/101

05420-000 São Paulo, SP

Brasil

E-mail: ocdobarr@usp.br

Publication supported by FAPESP.

Received September 24, 2001 Accepted November 27, 2002

\author{
${ }^{1}$ Faculdade de Medicina, Universidade de São Paulo, Lim-23, São Paulo, SP, Brasil \\ ${ }^{2}$ Serviço de Hematologia, Hospital dos Servidores do Estado de São Paulo, \\ São Paulo, SP, Brasil \\ ${ }^{3}$ Divisão de Hematologia, Instituto Adolfo Lutz, São Paulo, SP, Brasil \\ ${ }^{4}$ Hospital Vital Brazil, Instituto Butantan, São Paulo, SP, Brasil
}

\begin{abstract}
Eighty micrograms red blood cell (RBC) ghosts from patients who had previously exhibited the cutaneous form of loxoscelism (presenting localized dermonecrosis) and the viscerocutaneous form of loxoscelism (presenting dermonecrosis, hemoglobinuria, hematuria, and jaundice) and from controls were incubated with $2.5 \mu \mathrm{g}$ crude Loxosceles gaucho venom in $5 \mathrm{mM}$ phosphate buffer, $\mathrm{pH} 7.4$, at $37^{\circ} \mathrm{C}$. Among all membrane proteins, quantitative proteolysis of the important integral transmembrane protein 3 increased with venom dose and with incubation time from 30 to $120 \mathrm{~min}$, as demonstrated by gel densitometry. Similar quantitative data were obtained for RBC ghosts from patients and from control subjects, a fact that argues against the possibility of genetic factors favoring the hemolytic viscerocutaneous form. These data suggest that the clinical forms may be different types of the same disease, with the viscerocutaneous form being the result of large amounts of intravascularly injected venom and the superficial form being the result of in situ venom action. Since protein 3 is a housekeeping integral membrane protein, whose genetic deficiency leads to hemolytic anemia, it is reasonable to relate it to the hemolysis which occurs in the viscerocutaneous form of loxoscelism. The venom protease responsible for the process was not inhibited after 120-min incubation by $0.2 \mathrm{mM}$ paramethylsulfonyl fluoride or by $0.2 \mathrm{mM} \mathrm{N}$ ethylmaleimide but was inhibited by $25 \mathrm{mM}$ ethylenediaminetetraacetic acid (a calcium-chelating agent) in $5 \mathrm{mM}$ phosphate buffer at $\mathrm{pH}$ 7.4, which suggests that the enzyme is a calcium-dependent metalloprotease.
\end{abstract}

Key words

- Loxoscelism

- Loxosceles sp

- Spider venom

- Red blood cell membrane protein 3 


\section{Introduction}

The Loxosceles sp spider bite may cause two clinical variants of envenomation: a cutaneous form, which appears as a painful local lesion followed by necrosis, and a viscerocutaneous or systemic form which, in addition to the local lesion, exhibits hemolytic anemia together with hemoglobinuria, hematuria, jaundice and fever. Since this form only occurs in a small percent of cases, it has been claimed that a genetic factor may play an etiologic role in its occurrence. Thus, since hemolysis could be ascribed to hereditary glucose-6-phosphate dehydrogenase deficiency, Barretto et al. (1) investigated patients with the viscerocutaneous form, but found that only two of seven were glucose-6phosphate dehydrogenase deficient, a fact that ruled out a role of this deficiency in triggering hemolysis.

It is well known that the red blood cell (RBC) membrane structure and function depend on the membrane protein network, and the hereditary deficiency of spectrins, ankyrins, band 3 , band 4.1, and band 4.2 may lead to severe membrane disorders, triggering chronic hemolytic anemias. The spectrins, ankyrins, band 4.1 and band 4.2 are peripheral proteins or proteins which belong to the internal cytoskeleton and, together with other membrane proteins, the

Figure 1. SDS-PAGE of red blood cell ghosts from patients with the viscerocutaneous form of loxoscelism incubated with spider venom. The conditions are given in the legend to Table 1. The arrow on the left points to the position of band 3. No inhibitors were employed during ghost preparation. Lane 1, control ghosts without incubation; lane 2, control ghosts + venom with no incubation; lane 3, control ghosts + venom incubated for $30 \mathrm{~min}$; lane 4, control ghosts + venom incubated for $60 \mathrm{~min}$; lane 5, control ghosts + venom incubated for $120 \mathrm{~min}$.

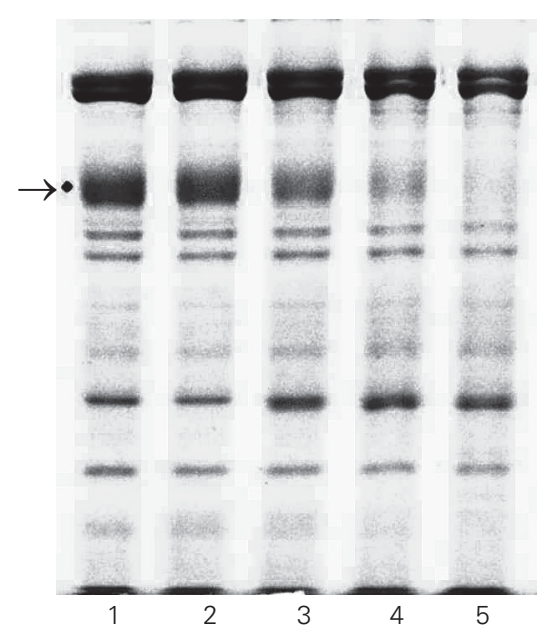

cytoskeleton is anchored to the integral proteins. These integral proteins, such as band 3 and the glycophorins, are firmly embedded in the membrane lipid bilayer. Band 3 works as a true internal anchor for the cytoskeleton and also presents an extracellular domain (2).

Since some proteases have been reported to be present in the venom of the most prevalent spider in the São Paulo area, Loxosceles gaucho (3), we determined the effect of its venom on RBC membrane proteins, which may explain the hemolytic effect occurring in the more severe form of the disease.

\section{Material and Methods}

Blood samples were collected from four patients who had previously presented the viscerocutaneous form, from four who had presented the cutaneous form of the disease and from four controls. RBC were washed three times with saline at $4^{\circ} \mathrm{C}$, and subsequently lysed 1:40 with $50 \mathrm{mM}$ phosphate buffer, $\mathrm{pH} 8.3$, at $4^{\circ} \mathrm{C}$. The membranes (ghosts) were washed with the same lysis buffer at least five times at $25,000 \mathrm{~g}$ at $4^{\circ} \mathrm{C}$ until a colorless solution of ghosts was obtained (4). The ghosts were aliquoted and stored at $-70^{\circ} \mathrm{C}$. No protease inhibitors were used during ghost preparation.

L. gaucho venom was obtained by spider gland electrostimulation at Instituto Butantan, and its content in protein was assessed. Eighty micrograms protein of RBC ghosts were incubated with $2.5 \mu \mathrm{g}$ crude venom in $50 \mathrm{mM}$ phosphate buffer, $\mathrm{pH} 8.3$, at $37^{\circ} \mathrm{C}$ for 0, 30, 60 and $120 \mathrm{~min}$. Other experiments were performed with increasing amounts of venom using the same concentration of ghosts. The samples were solubilized and applied to SDS-polyacrylamide gel (5), electrophoresis was carried out in $50 \mathrm{mM}$ Tris-

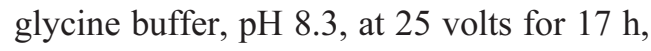
and the gels were stained with $0.05 \%$ Coomassie blue R250 and scanned with a Cellomatic densitometer. 
The following protease inhibitors from Sigma, St. Louis, MO, USA, were used to identify the class of the protease implicated in proteolysis: $0.2 \mathrm{mM}$ N-ethylmaleimide (NEM, a cysteine protease inhibitor), 0.2 $\mathrm{mM}$ phenylmethylsulfonyl fluoride (PMSF, a serine protease inhibitor), and $25 \mathrm{mM}$ ethylenediaminetetraacetic acid (EDTA, a metalloprotease inhibitor). RBC ghosts $(80 \mu \mathrm{g})$ from controls were also incubated with these protease inhibitors in $5 \mathrm{mM}$ phosphate buffer, $\mathrm{pH} 7.4$, at $37^{\circ} \mathrm{C}$ with $2.5 \mu \mathrm{g}$ L. gaucho venom for $120 \mathrm{~min}$.

At the time the investigation was performed there was no Ethics Committee at Instituto Butantan but informed consent was obtained from all patients,

\section{Results}

In order to investigate the effect of $L$. gaucho venom on the erythrocyte membrane proteins, $80 \mu \mathrm{g}$ RBC ghosts from patients with the cutaneous and viscerocutaneous forms as well as from control subjects were incubated with $2.5 \mu \mathrm{g}$ venom for 30,60 and $120 \mathrm{~min}$ (Figure 1). The degradation of RBC ghost protein 3 increased with incubation time with spider venom, as can be seen in Figure 1 and Table 1. The separation of venom proteins can also be observed in lane 1 of the figure, showing seven bands. The other lanes refer to another experiment which was performed with $100 \mu \mathrm{g}$ ghosts incubated for $60 \mathrm{~min}$ with increasing venom concentrations, showing increased band 3 proteolysis with increasing venom concentrations (Figure 2).

Band 3 degradation has been reported when only crude hemolysates are incubated at $37^{\circ} \mathrm{C}$, $\mathrm{pH} 8.0$, for 19 and $24 \mathrm{~h} \mathrm{(6),} \mathrm{a} \mathrm{fact}$ that was ascribed to the endogenous RBC proteases. However, the present experiments with venom did not exceed $120 \mathrm{~min}$, and thus any endogenous RBC protease activity certainly would be expected to be negligible in comparison with venom protease activity,
Table 1. Hydrolysis of red blood cell ghost band 3 from patients with the viscerocutaneous and the cutaneous forms of loxoscelism caused by venom from the Loxosceles gaucho spider.

\begin{tabular}{lcccc}
\hline & 0 min & $30 \min$ & 60 min & $120 \mathrm{~min}$ \\
\hline Controls $(\mathrm{N}=4)$ & $29.2 \pm 2.2$ & $20.7 \pm 3.9$ & $15.2 \pm 3.2$ & $6.5 \pm 3.1$ \\
Viscerocutaneous form $(\mathrm{N}=4)$ & $30.0 \pm 2.1$ & $20.2 \pm 3.4$ & $17.7 \pm 3.8$ & $7.5 \pm 3.4$ \\
Cutaneous form $(\mathrm{N}=4)$ & $29.7 \pm 1.7$ & $21.5 \pm 2.6$ & $11.0 \pm 2.2$ & $7.5 \pm 3.4$ \\
\hline
\end{tabular}

The ghosts $(80 \mu \mathrm{g})$ were incubated with $2.5 \mu \mathrm{g}$ venom in $100 \mu \mathrm{l}$ of $5 \mathrm{mM}$ phosphate buffer, $\mathrm{pH} 7.4$, at $37^{\circ} \mathrm{C}$. After SDS-PAGE (Figure 1), the protein content of band 3 was determined by densitometry. Data are reported as percentage of total applied protein.

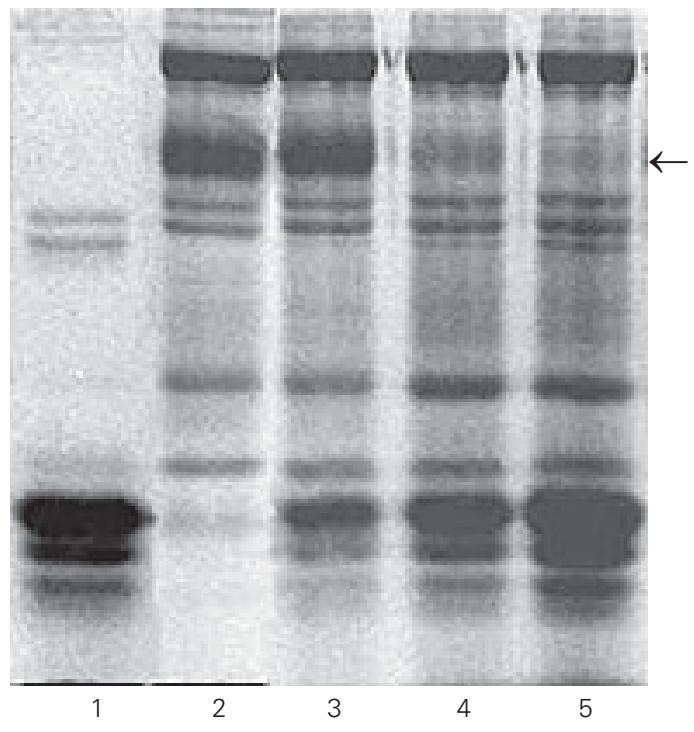

Figure 2. SDS-PAGE of the hydrolysate of red blood cell ghosts from normal patients obtained with increasing quantities of spider venom. The arrow on the right points to the position of band 3 . The hydrolysis was carried out on $100 \mu \mathrm{g}$ ghosts in $5 \mathrm{mM}$ phosphate buffer, $\mathrm{pH} 7.4$, at $37^{\circ} \mathrm{C}$ for $60 \mathrm{~min}$. No inhibitors were employed during ghost preparation. Lane 1, $100 \mu \mathrm{g}$ venom; lane 2, $100 \mu \mathrm{g}$ normal ghosts: lane 3, $100 \mu \mathrm{g}$ normal ghosts incubated with $25 \mu \mathrm{g}$ venom; lane 4, $100 \mu \mathrm{g}$ normal ghosts incubated with $50 \mu \mathrm{g}$ venom; lane 5, $100 \mu \mathrm{g}$ normal ghosts incubated with $100 \mu \mathrm{g}$ venom

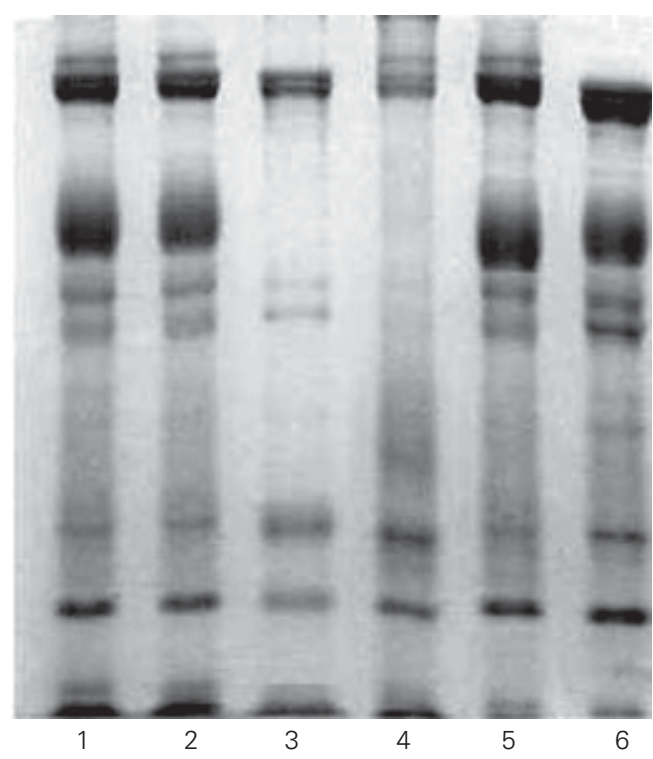

Figure 3. SDS-PAGE monitoring of the action of venom protease inhibitors on the digestion of red blood cell ghosts from normal patients by spider venom. Lane 1, normal ghosts not incubated with venom; lane 2, normal ghosts with 2.5 $\mu \mathrm{g}$ venom without incubation (0 min); lane 3, normal ghosts incubated with $2.5 \mu \mathrm{g}$ venom and $0.2 \mathrm{mM} \mathrm{N}$-ethylmaleimide for $120 \mathrm{~min}$; lane 4, normal ghosts incubated with $2.5 \mathrm{\mu g}$ venom and $0.2 \mathrm{mM}$ paramethylsulfonyl fluoride for $120 \mathrm{~min}$; lane 5, normal ghosts incubated with $2.5 \mu \mathrm{g}$ venom and $25 \mathrm{mM}$ ethylenediaminetetraacetic acid; lane 6, control ghosts. 
and the proteolysis observed in this study may be certainly ascribed to the action of the venom.

The experiment with protease inhibitors showed that neither NEM nor PMSF inhibited band 3 proteolysis. However, EDTA did inhibit band 3 proteolysis, as shown in Figure 3.

These data suggest that the putative protease(s) in L. gaucho venom is(are) calcium-dependent metalloprotease(s) since EDTA strongly chelates calcium. As can be seen in Figures 1, 2 and 3, band 3 degradation was always observed in addition to a much lesser and weak spectrin degradation.

\section{Discussion}

In all experiments protein 3 showed sound proteolysis, but the other membrane proteins did not seem to undergo proteolysis. As band 3 is an important integral transmembrane protein, whose genetic deficiency leads to severe spherocytic hemolytic anemia, it is reasonable to relate the band 3 proteolysis to the hemolysis which occurs in the viscerocutaneous form in vivo. Therefore, the hypothesis of a genetic trait which would predispose some individuals to a preferential band 3 proteolysis in the viscerocutaneous form of the disease seems unlikely.

However, if a genetic trait is not responsible for the viscerocutaneous form, what would be the hemolytic etiologic factor involved? And why do only a small percent of patients present hemolytic anemia after the spider bite? If it is accepted that the effect of the venom on transmembrane band 3 is the etiologic factor, we suggest that the viscerocutaneous form might be the result of a larger amount of venom inoculated at the site of the bite. Larger amounts of circulating venom may damage the RBC membrane and trigger hemolytic anemia. It is known that female Loxosceles sp spiders are bigger than males and yield twice as much venom (7). A female adult spider plenty of venom, i.e., that has not bitten any other animal yet, and a bite reaching a small vein would spread venom through the circulation, possibly explaining the hemolysis that only occurs in a few individuals.

All patients with the cutaneous or viscerocutaneous form of the disease exhibit local necrosis, and the viscerocutaneous form could thus be the most severe clinical manifestation of the same disease, not dependent on any predisposing genetic factor but rather on larger amounts of inoculated venom at the site of the bite. Moreover, the venom of a Loxosceles sp may be stronger than that of other species and variable amounts of venom could be inoculated at the site of the bite. It is known that $L$. laeta is the largest of Brazilian Loxosceles spiders. As a matter of fact, $L$. laeta spiders submitted to electrostimulation can produce $60 \mu \mathrm{g}$ of venom and L. intermedia and L. gaucho can produce 30-40 $\mu \mathrm{g}(8)$, suggesting that the clinical manifestations could be related to the amount of venom inoculated.

Indeed, in Chile, where L. laeta is the most prevalent species $(9,10)$, the incidence of the viscerocutaneous form of loxoscelism is $13 \%$ among all patients. In Brazil, L. gaucho is the most common species in São Paulo, and the incidence of the viscerocutaneous form is $3.1 \%$. In Curitiba, where $L$. intermedia is the most common species, the incidence of the viscerocutaneous form reaches $0.15 \%$ among all patients (11). In the State of Santa Catarina, where L. laeta is by far the most prevalent species, the incidence of the viscerocutaneous form reaches $13.1 \%$ (12).

Tambourgi et al. (13) reported in vitro complement-mediated hemolysis by the purified F35 venom protein as well as in vitro dose-dependent hemolysis. In another study, Tambourgi et al. (14) reported in vitro human complement-dependent hemolysis and $\mathrm{BALB} / \mathrm{c}$ mouse dermonecrosis induced by venom sphingomyelinase. Thus, a complement-mediated hemolysis caused by the 
venom and a direct action of the venom on the membrane band 3 protein, or both, may occur.

Accordingly, any individual could present both the cutaneous and viscerocutaneous forms depending on the volume of venom inoculated and the proteolytic activity of the venom. Thus, a superficial bite may lead to the cutaneous form, and a deeper bite with a large venom volume reaching a superficial vessel may trigger the viscerocutaneous form. Different spider sting sizes could also play an important role and a larger one may cause a deeper bite.

The proteolytic action of the venom on the band 3 extracellular domain may alter membrane properties making them sensitive to complement activation, with consequent intravascular hemolysis.

Interestingly, the cutaneous form, a very localized lesion, does not exhibit intravascular hemolysis (15), indicating that the venom does not reach the intravascular compartment in this clinical form. Therefore, we suggest that the two mechanisms may be triggered sequentially, with an initial direct proteolytic action on band 3 followed by further complement activation.

The present study has shown that band 3 of RBC ghosts is especially sensitive to $\mathrm{Lo}$ xosceles venom proteases. The suggestion that intravascularly inoculated venom leads to hemolysis requires additional in vivo experimental studies.

\section{References}

1. Barretto OCdeO, Cardoso JLC \& de Cillo D (1985). Viscerocutaneous form in loxoscelism and erythrocyte glucose-6-phosphate dehydrogenase deficiency. Revista do Instituto de Medicina Tropical de São Paulo, 27: 264-267.

2. Palek J (1995). The red cell membrane. In: Beutler E, Marshall AL, Coller BS \& Kipps TJ (Editors), Williams Hematology. McGraw-Hill Inc., New York, NY, USA

3. Rosenfeld G (1982). Acidentes por animais peçonhentos. In: Veronesi R (Editor), Doenças Infecciosas e Parasitárias. 7th edn. Guanabara Koogan, Rio de Janeiro, RJ, Brazil, 1068.

4. Dodge JT, Mitchell C \& Hanahan DJ (1963). The preparation and chemical characteristics of hemoglobin free ghosts of human erythrocytes. Archives of Biochemistry and Biophysics, 100: 119-130.

5. Laemmli UK (1970). Cleavage of structural proteins during the assembly of the head of bacteriophage T4. Nature, 227: 680-685.

6. Tarone G, Hamasaki N, Fukuda M \& Marchesi VT (1979). Proteolytic degradation of human erythrocyte band 3 by membrane associated protease activity. Journal of Membrane Biology, 48: 1-12.

7. Oliveira KC, Andrade RMG, Giusti Al, Silva WD \& Tambourgi DV (1999). Sex-linked variation of Loxosceles intermedia spider venoms. Toxicon, 37: 217-221.

8. Lucas S \& Meir J (1995). Biology and distribution of spiders of medical importance. In: Meir J \& White J (Editors), Handbook of Clinical Toxicology of Animal Venoms and Poisons. CRC Press, Boca Ratton, FL, USA, 240-258.

9. Suarez G, Biggermann U \& Schenone H (1971). Estudios bioquímicos del veneno de Loxosceles laeta y de sus mecanismos de accíon.
Boletin Chileno de Parasitologia, 26: 60-62.

10. Schenone H \& Suarez G (1978). Venoms of Scytodidae, genus Loxosceles. In: Bettini S (Editor), Arthropod Venoms. Chapter II. Springer Verlag, Berlin, Germany, 247-275.

11. Ministério da Saúde, Brasil (1999). Manual de Diagnóstico e Tratamento de Acidentes por Animais Peçonhentos. Assessoria de Comunicação Social, Fundação Nacional de Saúde, Brasília, DF, Brazil, 60.

12. Sezerino UM, Zannin M, Coelho IK, Gonçalves Junior J, Grando M, Mattosinho SG, Cardoso JLC, Von Eickstedt VC, França FOS, Barbaro KC \& Fan HW (1998). A clinical and epidemiological study of Loxosceles spider envenoming in Santa Catarina, Brazil. Transactions of the Royal Society of Tropical Medicine and Hygiene, 92: 546-548.

13. Tambourgi DV, Magnoli FC, Von Eickstedt VRD, Benedetti ZC, Petricevich VL \& Silva WD (1995). Incorporation of a 35-kilodalton purified protein from Loxosceles intermedia spider venom transforms human erythrocytes into activators of autologous complement alternative pathway. Journal of Immunology, 155: 4459-4466.

14. Tambourgi DV, Magnoli FC, Van Den Berg CW, Morgan BP, Araujo PS, Elias W, Alves EW \& Silva WD (1998). Sphingomyelinases in the venom of the spider Loxosceles intermedia are responsible for both dermonecrosis and complement-dependent hemolysis. Biochemical and Biophysical Research Communications, 251: 366-373.

15. Morena P, Nonoyama K, Cardoso JLC \& Barretto OCdeO (1994). Search of intravascular hemolysis in patients with the cutaneous form of loxoscelism. Revista do Instituto de Medicina Tropical de São Paulo, 36: 149-151. 